\title{
Kemampuan Komunikasi Karyawan Kantor Depan dan Kepuasan Tamu di Wisma DPR RI Bogor
}

\author{
Mamat Syamsudin, Agustina Multi Purnomo, Ali Alamsyah Kusumadinata \\ Fakultas Ilmu Sosial dan Politik, Universitas Djuanda \\ Email corresponding authors: agustina.m@unida.ac.id
}

\begin{abstract}
ABSTRAK
Kemampuan teknis karyawan kantor depan terkait erat dengan kemampuan komunikasi karyawan kantor depan dan kemampuan komunikasi karyawan kantor depan merupakan bagian penting dalam mendukung kepuasan tamu. Oleh karenanya, penelitian ini mengkaji hubungan antara kualitas komunikasi karyawan kantor depan dalam melayani tamu dan kepuasan tamu di Wisma DPR RI Bogor. Penelitian di hotel milik pemerintah dengan tamu berasal dari satu kelompok tamu masih jarang dilakukan. Penelitian ini menggunakan metode penelitian kuantitatif melalui survey terhadap 100 orang tamu. Pengolahan data kemampuan komunikasi karyawan kantor depan dan kepuasan tamu menggunakan Weight Mean Skor dan penentuan interval antara satu kriteria dengan kriteria lainnya. Analisis hubungan antarvariabel menggunakan regresi berganda dan membandingkan dengan perhitungan koefisien. Hasil penelitian menunjukkan Keterampilan komunikasi karyawan kantor depan berpengaruh signifikan terhadap kepuasan tamu di Wisma DPR RI Bogor. Nilai koefisien menunjukkan terdapat pengaruh y faktor lain yang mempengaruhi kepuasan tamu di Wisma DPR RI Bogor selain faktor keterampilan komunikasi karyawan kantor depan. Faktor-faktor yang mungkin mempengaruhi kepuasan tamu selain kemampuan komunikasi karyawan kantor depan dapat diketahui melalui penelitian lain.
\end{abstract}

Kata Kunci: Kemampuan komunikasi, karyawan kantor depan, hotel, kepuasan pelanggan

\section{PENDAHULUAN}

Pelayanan merupakan bagian penting dalam hotel. Hotel merupakan jasa pelayanan menginap dan akomodasi (Sulistiyono, 2011, p. 15). Jasa penginapan sebagai produk utama hotel serta jasa-jasa pendukung lain seperti jasa layanan pertemuan, makanan dan minuman mengandalkan kemampuan pelayanan dari seluruh karyawan hotel.

Hotel memiliki beragam bagian dalam upaya memberikan pelayanan kepada pengunjung. Struktur organisasi hotel secara umum terdiri dari pemilik, manajer umum, pengendali, serta manajer pembelian, sumberdaya manusia, teknis mesin, kantor depan, pemasaran, makanan dan minuman (Bardi, 2003, p. 38). Struktur organisasi hotel berkembang sesuai dengan jenis, bentuk dan kebijakan pemilik hotel. Setiap bagian dari struktur organisasi hotel berperan dalam memberikan layanan terhadap tamu hotel (Chen, 2017; Kang \& Busser, 2018; Nafik, 2018; Paryoga, 2020).

Karyawan kantor depan memengang peran penting dalam pengelolaan hotel. Karyawan kantor depan (front-line staff) berperan dalam membangun citra dan layanan hotel (Williams \& Buswell, 2003, p. 10). Seorang karyawan kantor depan harus memiliki kemampuan untuk menangani permintaan tamu, kemampuan mengarahkan karyawan lain, komunikasi antar-bagian dalam hotel dan dengan pengunjung serta kemampuan menyajikan informasi keuangan di kantor depan (Bardi, 2003, p. 48). 
Kemampuan komunikasi karyawan kantor depan merupakan bagian penting dalam pelayanan hotel terutama komunikasi dengan tamu. Tanpa kemampuan komunikasi karyawan kantor depan, layanan hotel tidak dapat disampaikan dengan baik kepada tamu dan pada akhirnya menyebabkan tamu tidak puas terhadap layanan hotel (Bardi, 2003, p. 60). Masalah pada kemampuan komunikasi karyawan kantor depan berpengaruh negatif terhadap kepuasan pelanggan dan produktivitas hotel (Sayin \& Karaman, 2018; Sudantari, Padmadewi \& Dewi, 2019; Husein, 2019).

Keterampilan yang perlu dimiliki oleh karyawan kantor depan di hotel yaitu persyaratan pengetahuan (ketrampilan), kemampuan berkomunikasi dan sikap (Wardoyo, 1996, p. 36). Selanjutnya, Wardoyo (1996) menjelaskan, keterampilan teknis yang perlu dimiliki oleh setiap karyawan kantor depan hotel adalah pengetahuan, ramah dan sopan, kepribadian yang baik, murah senyum, penampilan, loyalitas dan dedikasi, disiplin, efisien, praktis, jujur dan memiliki rasa percaya diri.

Keterampilan komunikasi karyawan kantor depan terdiri dari keterampilan komunikasi verbal dan non verbal (Ondy \& Eleazar, 2017; Sayin \& Karaman, 2017; Simanjuntak, 2020). Keterampilan komunikasi verbal dan non verbal merupakan keterampilan komunikasi interpersonal (Pope, 2015). Kualitas komunikasi verbal dan non verbal dalam konteks karyawan di industri pelayanan menunjukkan kualitas komunikasi dari karyawan dan institusi terkait (Hardjati \& Febrianita, 2019). Komunikasi verbal adalah komunikasi dengan menggunakan bahasa, kata-kata, suara, lambang atau kode. Komunikasi verbal dapat berlangsung secara lisan dan tulisan (Sugiyono, 2005, p. 117). Komunikasi non verbal merupakan komunikasi yang menggunakan simbol non verbal. Pesan nonverbal dikelompokkan ke dalam pesan gestur, jarak, kebendaan, kinesik, kebahasaan, sentuhan, aroma, dan isyarat (Hidayat, 2012, pp. 15-17).

Kemampuan komunikasi karyawan kantor depan merupakan bagian dari upaya membangun kepuasan tamu sebagai tujuan layanan hotel. Kepuasan konsumen (atau tamu dalam konteks layanan hotel, pen) adalah perasaan senang atau kecewa seseorang yang muncul setelah membandingkan kinerja atau hasil produk yang dipikirkan terhadap kinerja yang diharapkan (Kotler \& Keller, 2007). Kepuasan pelanggan dipengaruhi oleh hubungan baik dengan pengelola layanan (Mahafzah et. al., 2020). Hubungan baik tersebut terbangun salah satunya melalui komunikasi dengan karyawan hotel (Silaban, Pasaribu \& Silalahi, 2019; Rossanty, Nasution \& Irawan, 2019; Nikmah, Emita \& Boyratan, 2019). Tingkat kepuasan tamu ditentukan oleh lima faktor utama dan harus diperhatikan oleh hotel, yaitu kualitas produk, kualitas pelayanan, emosional, harga, dan biaya-biaya lain yang harus dikeluarkan tamu (Kotler \& Keller, 2007:177).

Karakter tamu mempengaruhi kepuasan pelanggan (Permatasari, 2020; Mulyana \& Prayetno, 2018) dan mempengaruhi kepuasan layanan karyawan kantor depan (Shao, 2017). Wisma DPR RI Bogor merupakan hotel milik pemerintah dan melayani tamu dari kalangan pemerintah. Wisma DPR RI Bogor di bawah pengelolaan Sekretariat Jenderal dan Badan Keahlian DPR RI dan menyediakan pelayanan penginapan dan kegiatan rapat dinas terutama untuk anggota DPR RI. Wisma DPR RI berbeda dengan bentuk layanan penginapan lain karena memiliki karakter tamu tetap yaitu perangkat DPR RI dan keluarga.

Wisma DPR RI berlokasi di jalur wisata Puncak Bogor di Cisarua Kabupaten Bogor Jawa Barat. Wisma DPR RI Bogor memiliki fasilitas antara lain ruang rapat, ruang serbaguna, bungalow untuk istirahat, lapangan olah raga, kolam renang dan taman bermain anak.

Penelitian ini mengkaji hubungan antara kualitas komunikasi karyawan kantor depan dalam melayani tamu dan kepuasan tamu di Wisma DPR RI Bogor. Kesebelas keterampilan teknis kantor depan (Wardoyo, 1996, p. 36) memiliki aspek verbal dan non verbal. Oleh karena itu, penelitian ini akan mengkaji kemampuan verbal dan non verbal karyawan kantor 
depan dalam menjalankan kesebelas keterampilan teknis kantor depan. Variabel kepuasan pelanggan menggunakan indikator kepuasan pelanggan menurut Kotler dan Keller (2007, p. 177). Wawancara pendahuluan terhadap karyawan kantor depan Wisama DPR RI menunjukkan kelima indikator kepuasan pelanggan tidak berkaitan seluruhnya dengan kinerja karyawan kantor depan. Di Wisma DPR RI, kualitas kamar, makanan dan minuman tidak ditentukan oleh karyawan kantor depan. Kualitas kamar ditentukan oleh kinerja staf house keeping. Kualitas makanan dan minuman ditentukan oleh staf dapur atau restoran. Kualitas pelayanan melibatkan seluruh karyawan hotel. Harga dan biaya-biaya lain terkait dengan kebijakan pengelola. Oleh karenanya, keterkaitan antara kepuasan pelanggan dengan layanan karyawan kantor depan diduga merupakan hasil kemampuan komunikasi verbal dan non verbal karyawan kantor layanan hotel kepada tamu.

Penelitian ini dapat menjadi masukan dalam kajian kualitas komunikasi karyawan kantor depan di hotel milik pemerintah dengan karakter tamu utama dari kelompok tertentu. Kajian ini masih jarang dilakukan. Kajian kualitas komunikasi karyawan kantor depan biasanya dilakukan di hotel umum (Putra, 2019; Isnani \& Setiyariski, 2020; Sukamerta \& Andiani, 2020).

\section{METODOLOGI PENELITIAN}

Pengolahan data keterampilan komunikasi dilakukan berdasarkan variabel keterampilan komunikasi verbal dan non verbal pada sebelas bentuk keterampilan yang harus dimiliki oleh seorang karyawan kantor depan (Wardoyo, 1996). Kesebelas bentuk keterampilan karyawan kantor depan tersebut ditanyakan kepada karyawan kantor depan Wisma DPR RI. Hasil wawancara menunjukkan beberapa keterampilan memiliki aspek verbal dan non verbal atau keduanya. Aspek-aspek verbal dan non verbal di tataran aplikatif di karyawan kantor depan Wisma DPR RI adalah:

Tabel 1. Kualifikasi Staf Kantor Depan Berdasarkan Aspek Komunikasi Verbal dan Non Verbal

\begin{tabular}{lll}
\hline $\begin{array}{c}\text { Kualifikasi Karyawan } \\
\text { Kantor Depan }\end{array}$ & \multicolumn{1}{c}{ Verbal } & \multicolumn{1}{c}{ Non Verbal } \\
\hline Pengetahuan & $\begin{array}{l}\text { Pengetahuan } \\
\text { informatif mengenai } \\
\text { kondisi dan fasilitas }\end{array}$ & \\
Ramah dan sopan & & $\begin{array}{l}\text { Sikap yang menunjukkan } \\
\text { keramahan dan kesopanan } \\
\text { Sepribadian yang baik }\end{array}$ \\
Murah senyum & $\begin{array}{l}\text { Sikap yang menunjukkan } \\
\text { kepribadian yang baik }\end{array}$ \\
Penampilan & $\begin{array}{l}\text { Sikap ceria dan murah senyum } \\
\text { Seragam kerja yang disediakan } \\
\text { oleh perusahaan, instansi } \\
\text { pemerintah dengan lengkap, rapi } \\
\text { dan bersih di samping kebersihan }\end{array}$ \\
& & $\begin{array}{l}\text { dan perawatan diri yang baik } \\
\text { Melaksanakan perintah serta }\end{array}$ \\
Loyalitas dan dedikasi & & $\begin{array}{l}\text { penyelesaian tugas-tugas dengan } \\
\text { baik }\end{array}$ \\
& & Sikap yang menunjukkan \\
kisiplin & & kedisiplinan \\
Efisien & &
\end{tabular}


Praktis

dengan lugas, singkat dan jelas

Jujur

Rasa percaya diri Sumber: Diolah dari Wardoyo (1996, p. 36) dan hasil wawancara terhadap karyawan kantor depan di Wisma DPR RI (2020)

Wawancara dengan karyawan kantor depan menunjukkan aspek keterampilan komunikasi verbal lebih nampak pada keterampilan karyawan kantor depan bagian pengetahuan. Wawancara dengan karyawan kantor depan menunjukkan aspek keterampilan komunikasi verbal juga meliputi dua dimensi, cara berbicara serta komunikasi singkat dan jelas. Aspek keterampilan karyawan kantor depan lain dianggap lebih banyak dinilai oleh tamu dari keterampilan non verbal karyawan kantor depan.

Kepuasan tamu diukur berdasarkan variabel kualitas produk, kualitas pelayanan, emosional, harga, dan biaya-biaya lain yang harus dikeluarkan tamu (Kotler \& Keller, 2007:177). Hubungan antar-variabel dalam penelitian ini dapat diamati pada Gambar 1 .

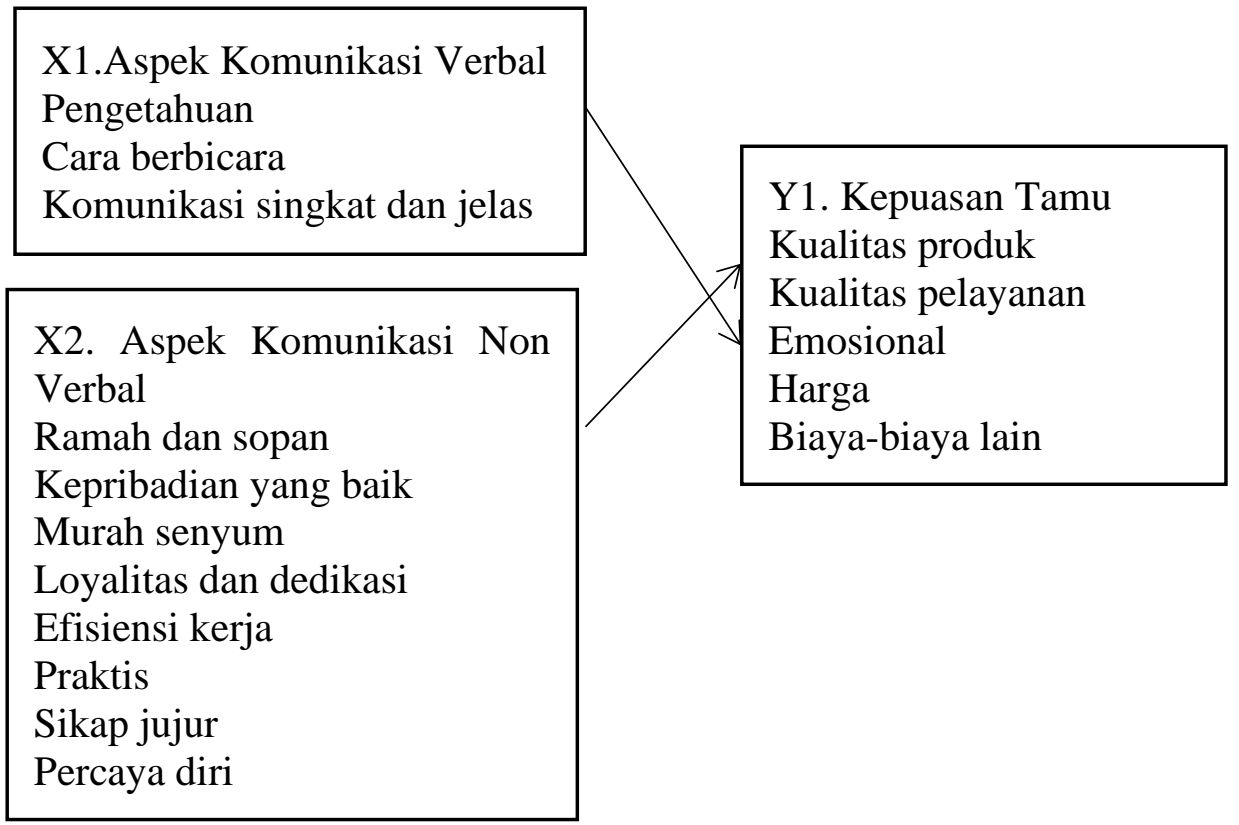

Gambar 1. Hubungan antar variabel

Angket disusun dengan menggunakan skala Likert dengan skala 1-5 yang menunjukkan ukuran sangat tidak baik, tidak baik, cukup, baik dan sangat baik. Uji validitas angket menggunakan pengujian korelasi Bivariate Pearson (Produk Momen Pearson). Hasil uji validitas menunjukkan seluruh variabel memiliki nilai $r$ hitung $\geq \mathrm{r}$ tabel sebesar 0.1966 atau dinyatakan valid kecuali untuk dimensi penampilan dan disiplin. Oleh karenanya kedua dimensi ini dikeluarkan dari pengukuran aspek non verbal. 
Nilai signifikansi dari kedua variabel $\mathrm{X}$ kurang dari $\alpha=0,05$. Ini berarti seluruh variabel dalam angket dinyatakan valid sehingga dapat digunakan sebagai instrumen penelitian. Uji reliabilitas menggunakan uji Cronbach's Alpha. Hasil uji reliabilitas menunjukkan nilai koefisien reliabilitas $\mathrm{X}_{1}$ sebesar 0,811, $\mathrm{X}_{2}$ sebesar 0,861 dan $\mathrm{Y}$ sebesar 0,896 . Nilai tersebut lebih dari $\alpha=0,05$. Seluruh variabel reliable atau konsisten, sehingga dapat digunakan sebagai instrument penelitian.

Jumlah sampel dalam penelitian ini ditentukan dengan menggunakan rumus Slovin. Jumlah populasi mengacu pada data kunjungan ke Wisma DPR RI Bogor tahun 2019 yaitu sebanyak 6.900 orang per bulan yang secara periodik berkunjung dan menginap pada bulan November sampai dengan bulan April. Data bulan April tahun 2020 dan seterusnya tidak diperhitungkan karena pada waktu tersebut Wisma DPR RI Bogor membatasi kunjungan untuk mengindari penyebaran pandemi virus COVID-19.

$$
n=\frac{\mathrm{N}}{1+\left(\mathrm{Ne}^{2}\right)}
$$

Keterangan:

$$
\begin{aligned}
\mathrm{n} & =\text { Jumlah Sampel } \\
\mathrm{N} & =\text { Jumlah populasi } \\
\mathrm{Ne}^{2}= & \text { Batas ketelitian yang diinginkan (persen kelonggaran ketidaktelitian karena } \\
& \begin{aligned}
& \text { kesalahan penarikan sampel). } \\
& \mathrm{N}=\frac{6.900}{1+\left(6.900 \times 0.1^{2}\right)} \\
&=98.57=99
\end{aligned}
\end{aligned}
$$

Jumlah sampel yang di ambil dalam penelitian ini sebanyak 99 orang pembulatan menjadi 100 orang.

Seluruh variabel dalam angket diolah diolah dengan menggunakan Weight Mean Skor dengan menggunakan rumus:

$$
M=\sum f(x) / n
$$

Keterangan:

$$
\begin{aligned}
& \begin{array}{l}
\mathrm{M}=\text { Perolehan angka penafsiran atau kriteria } \\
\text { penafsiran }
\end{array} \\
& \begin{array}{l}
\sum=\text { Penjumlahan } \\
\mathrm{f}=\text { Frekuensi jawaban responden } \\
\mathrm{x}=\text { Pembobotan } \\
\mathrm{n}=\text { Jumlah sampel penelitian }
\end{array}
\end{aligned}
$$

Alternatif jawaban menggunakan urutan kedudukan yang mengantarkan perbedaan tingkat skala dari angka yang tertinggi sampai ke angka yang terendah. Penentuan kriteria penafsiran mengacu pada interval antara satu kriteria dengan kriteria lainnya. Penentuan interval adalah sebagai berikut:

$\mathrm{I}=$ nilai tertinggi - nilai terendah $/ \mathrm{n}$

Maka I $=5-1 / 5=0,8$

Pengukuran kemampuan komunikasi karyawan kantor depan bertujuan untuk meningkatkan kepuasan tamu di Wisma DPR RI. Hubungan antara tiga atau lebih variabel (dua atau lebih variabel dependen dan satu variabel independen) biasanya menggunakan korelasi berganda atau regresi berganda. Korelasi berganda berkaitan dengan interkolasi variabel variabel independen sebagaimana korelasi mereka dengan variabel dependen. Korelasi berganda adalah suatu nilai yang memberikan kuatnya pengaruh atau hubungan dua 
variabel atau lebih secara bersama sama dengan variabel lain (Riduwan, 2012, p. 238). Regresi berganda adalah regresi dengan dua variabel bebas (misalnya $\mathrm{X}_{1}$ dan $\mathrm{X}_{2}$ ) dan satu variabel terikat (Y). Mengacu pada perumusan masalah, persamaan garis regresi bagi masing-masing variabel bebas dapat dilakukan dengan cara perhitungan regresi linier sederhana, yakni regresi $\mathrm{Y}$ atas $\mathrm{X}_{1}$ dan regresi $\mathrm{Y}$ atas $\mathrm{X}_{2}$. Oleh karena itu, penelitian ini menganalisis hubungan antara kemampuan komunikasi karyawan kantor depan dengan kepuasan tamu dengan regresi berganda.

Peneliti mengukur sejauh mana variabel $\mathrm{X}$ (kemampuan komunikasi) memberikan kontribusi terhadap Y (kepuasan tamu) dengan menggunakan perhitungan koefisien $(\mathrm{Kd})$ :

$\mathrm{Kd}=\mathrm{p}^{2} \mathrm{x} 100 \%$

Keterangan:

$\mathrm{Kd}=$ Koefisien determinasi

$\mathrm{P} \quad=$ Koefisien korelasi

Peneliti menggunakan uji t untuk menunjukan pengaruh satu variabel independen secara individual dalam menerangkan variabel dependen (Ghojali, 2011). Peneliti melakukan pengujian hipotesis nol (Ho) dan hipotesis alternatif (Ha) untuk mengetahui kebenaran dari pehitungan analisis korelasi. Hipotesis penelitian ini adalah:

Ho: $\mathrm{p}=0$ : Tidak ada pengaruh antara komunikasi petugas front office dengan kepuasan pengunjung di Wisma DPR RI

Ha: $p \neq 0$ : Ada pengaruh antara antara komunikasi petugas front office dengan kepuasan pengunjung di Wisma DPR RI Bogor.

Pengujian hipotesis menggunakan statistik t. Rumus yang digunakan menurut Sugiyono (2013, p. 230) sebagai berikut.

$$
\mathrm{t}=\mathrm{r} \frac{\sqrt{n-2}}{\sqrt{1-r^{2}}}
$$

Keterangan:

$r=$ Koefisien korelasi

$\mathrm{t}=$ thitung yang selanjutnya dibandingkan dengan $\mathrm{t}$ tabel

$\mathrm{n}=$ Jumlah data dan observasi

Kriteria Keputusan uji t tersebut adalah: Bila t hitung lebih kecil atau sama dengan $\mathrm{t}$ tabel ( $\mathrm{t}$ hitung $\leq \mathrm{t}$ tabel) pada $\alpha=0,05$ maka Ho diterima dan Ha ditolak, artinya kemampuan komunikasi karyawan kantor depan (X) tidak mempunyai pengaruh terhadap kepuasan tamu (Y). Jika $t$ hitung lebih besar dari $t$ tabel ( $\mathrm{t}$ hitung $\geq \mathrm{t}$ tabel ) pada $\alpha=0,05$ maka Ha diterima dan Ho ditolak, artinya kemampuan komunikasi karyawan kantor depan (X) berpengaruh terhadap kepuasan tamu (Y).

\section{HASIL DAN PEMBAHASAN}

\section{Kemampuan Komunikasi Verbal}


Survey terhadap 100 orang responden menunjukkan nilai rata- rata dari keseluruhan dimensi adalah 4,53. Ini menunjukan bahwa keterampilan komunikasi verbal karyawan kantor depan sudah sesuai dengan apa yang diharapkan oleh tamu.

Tabel 2. Rekapitulasi Nilai Variabel Komunikasi Verbal (X1) di Wisma DPR RI Bogor

\begin{tabular}{llcc}
\hline \multicolumn{1}{c}{ Dimensi } & \multicolumn{1}{c}{ Indikator } & M & $\begin{array}{c}\text { Kriteria } \\
\text { Penafsiran }\end{array}$ \\
\hline Pengeta-huan & Menguasai layanan hotel & 5,58 & Sangat baik \\
& Menguasai bahasa asing & 4,74 & Sangat Baik \\
& Menguasai informasi lain & 4,70 & Sangat Baik \\
& Jumlah & $\mathbf{5 , 0 0}$ & Sangat Baik \\
\hline Cara & Berbicara hal penting & 4,20 & Baik \\
menyampaik & Berbicara dengan baik & 3,86 & Baik \\
an informasi & Pemilihan kata & 3,79 & Baik \\
& Jumlah & $\mathbf{3 , 9 5}$ & Baik \\
\hline Komuni-kasi & Cepat menjawab pertanyaan tamu & 4,61 & Sangat Baik \\
singkat dan & Jelas dalam penyampaian informasi & 4,69 & Sangat Baik \\
jelas & Jumlah & $\mathbf{4 , 6 5}$ & Sangat Baik \\
\hline \multicolumn{2}{c}{ Rata-rata } & $\mathbf{4 , 5 3}$ & Sangat Baik \\
\hline
\end{tabular}

Sumber: Hasil Penelitian, 2020

Pengetahuan sebagai aspek keterampilan karyawan kantor depan yang diukur dari keterampilan verbal menunjukkan kriteria penafsiran sangat baik. Ini menunjukkan karyawan kantor depan Wisma DPR RI telah menunjukkan secara verbal jika mereka memiliki pengetahuan cukup baik mengenai hotel dan layanan hotel. Kriteria penafsiran responden terhadap keterampilan komunikasi karyawan kantor depan baik hanya pada dimensi cara berbicara. Ini menunjukkan cara berbicara karyawan kantor depan Wisma DPR RI masih perlu ditingkatkan.

\section{Kemampuan Komunikasi Non verbal}

Survey terhadap 100 orang responden menunjukkan nilai rata- rata dari keseluruhan dimensi adalah 4,06. Ini menunjukan bahwa keterampilan komunikasi non verbal karyawan kantor depan masih lebih lemah dibandingkan dengan keterampilan komunikasi verbal.

Penilaian tamu terhadap kemampuan komunikasi non verbal karyawan kantor depan di Wisma DPR RI menunjukkan nilai rata-rata tertinggi ada pada kemampuan teknis praktis. Kemampuan teknis karyawan kantor depan murah senyum, ramah dan sopan, kepribadian yang baik, sikap yang menunjukan loyalitas dan dedikasi, jujur dan percaya diri mendapatkan kriteria penilaian baik. Ini menunjukkan kemampuan komunikasi non verbal karyawan kantor depan dalam menunjukkan keterampilan teknis teknis karyawan kantor depan masih memerlukan perbaikan.

Tabel 3. Rekapitulasi Nilai Variabel Komunikasi Non Verbal (X2) di Wisma DPR RI Bogor

\begin{tabular}{llll}
\hline Dimensi & Indikator & M & Kriteria \\
\hline
\end{tabular}




\begin{tabular}{|c|c|c|c|}
\hline & & & Penafsiran \\
\hline \multirow{5}{*}{$\begin{array}{l}\text { Ramah dan } \\
\text { sopan }\end{array}$} & Penampilan bersih dan rapi & 4,73 & Sangat baik \\
\hline & Pegawai selalu tersenyum kepada tamu & 3,90 & Baik \\
\hline & Pegawai selalu menyapa terhadap tamu & 3,72 & Baik \\
\hline & Pegawai selalu mengucapkan salam terhadap tamu & 3,61 & Baik \\
\hline & Jumlah & 3,99 & Baik \\
\hline \multirow[t]{4}{*}{$\begin{array}{l}\text { Kepribadian } \\
\text { yang baik }\end{array}$} & $\begin{array}{l}\text { Membantu tanpa pamrih tidak mengharapkan } \\
\text { imbalan }\end{array}$ & 4,04 & Baik \\
\hline & Bersikap hormat terhadap tamu & 4,05 & Baik \\
\hline & Bertanggung jawab dengan bekerja sepenuh hati & 4,05 & Baik \\
\hline & Jumlah & 4,04 & Baik \\
\hline \multirow{4}{*}{$\begin{array}{l}\text { Murah } \\
\text { senyum }\end{array}$} & Tidak bersikap acuh tak acuh & 4,04 & Baik \\
\hline & Sikap Ceria & 4,05 & Baik \\
\hline & Menunjukan sikap ramah & 4,05 & Baik \\
\hline & Jumlah & 4,05 & Baik \\
\hline \multirow{5}{*}{$\begin{array}{l}\text { Sikap yang } \\
\text { menunjukan } \\
\text { loyalitas dan } \\
\text { dedikasi }\end{array}$} & Memiliki semangat tinggi & 4,03 & Baik \\
\hline & Memiliki sikap melayani & 4,07 & Baik \\
\hline & $\begin{array}{l}\text { Memiliki komitmen tinggi dalam menyelesaikan } \\
\text { pekerjaan }\end{array}$ & 4,06 & Baik \\
\hline & Disiplin kerja terhadap organisasi & 4,04 & Baik \\
\hline & Jumlah & 4,05 & Baik \\
\hline \multirow{3}{*}{$\begin{array}{l}\text { Sikap yang } \\
\text { menunjukan } \\
\text { Efesiensi } \\
\text { kerja } \\
\end{array}$} & Bersikap teliti dalam bekerja & 3,82 & Baik \\
\hline & Bersikap tidak mengulur waktu pekerjaan & 4,08 & Baik \\
\hline & Jumlah & 3,95 & Baik \\
\hline \multirow[t]{3}{*}{ Praktis } & Mudah dalam pelayanan & 4,33 & Sangat Baik \\
\hline & Cepat dalam pelayanan & 4,30 & Sangat Baik \\
\hline & Jumlah & 4,31 & Sangat Baik \\
\hline \multirow[t]{3}{*}{ Jujur } & Tidak melakukan kecurangan dalam bekerja & 4,06 & Baik \\
\hline & Bersikap memenuhi janji & 4,04 & Baik \\
\hline & Jumlah & 4,05 & Baik \\
\hline \multirow[t]{5}{*}{ Percaya diri } & Tidak mudah putus asa & 4,04 & Baik \\
\hline & Bersikap positif & 4,04 & Baik \\
\hline & Menerima tantangan baru & 4,09 & Baik \\
\hline & Jumlah & 4,05 & Baik \\
\hline & Rata-rata & 4,06 & Baik \\
\hline
\end{tabular}

\section{Kepuasan Tamu}

Berdasarkan hasil tabel rekapitulasi variabel kepuasan tamu, maka nilai yang diperoleh dari seluruh dimensi yaitu sebesar 4,70 atau masuk pada kriteria penafsiran sangat baik. Nilai rata-rata terendah terdapat pada dimensi kualitas pelayanan yaitu sebesar 4,32 dan nilai ratarata tertinggi terdapat pada dimensi biaya. Tamu di Wisma DPR RI Bogor tidak dikenakan biaya tambahan apapun kecuali biaya penggunaan fasilitas. Kebijakan ini mendapat respon positif dari tamu.

Tabel 4. Rekapitulasi Nilai Variabel Kepuasan Tamu (Y) di Wisma DPR RI Bogor

\begin{tabular}{cccc}
\hline Dimensi & Indikator & M & Kriteria \\
\hline
\end{tabular}




\begin{tabular}{llcc}
\hline & & & Penafsiran \\
\hline Kualitas produk & Produk berkalitas & 4,73 & Sangat baik \\
& Bangunan yang memenuhi kriteria & 4,85 & Sangat Baik \\
& Fasilitas yang memadai dan & 4,80 & Sangat Baik \\
& berfungsi dengan baik & & \\
& Jumlah & $\mathbf{4 , 7 9}$ & Sangat Baik \\
\hline Kualitas pelayanan & Pelayanan yang sigap & 4,39 & Sangat Baik \\
& Ketepatan waktu pelayanan & 4,28 & Sangat Baik \\
& Tanggap terhadap keluhan tamu & 4,25 & Sangat Baik \\
& Kesiapan untuk merespon & 4,37 & Sangat Baik \\
& permintaan tamu & & \\
& Jumlah & $\mathbf{4 , 3 2}$ & Sangat Baik \\
\hline Emosional & Sabar & 4,56 & Sangat Baik \\
& Bersahabat & 4,49 & Sangat Baik \\
& Membantu & 4,45 & Sangat Baik \\
& Jumlah & $\mathbf{4 , 5 0}$ & Sangat Baik \\
\hline Harga & Harga relatf murah & 4,93 & Sangat Baik \\
& Jumlah & $\mathbf{4 , 9 3}$ & Sangat Baik \\
\hline Biaya & Tidak adanya biaya tambahan & 4,96 & Sangat Baik \\
& Jumlah & $\mathbf{4 , 9 6}$ & Sangat Baik \\
\hline & Rata-rata & $\mathbf{4 , 7 0}$ & Sangat Baik \\
\hline
\end{tabular}

\section{Hubungan antara Kemampuan Komunikasi dengan Kepuasan Tamu}

Hasil penghitungan korelasi linear berganda dengan menggunakan aplikasi SPSS antara variabel $\mathrm{X}_{1}, \mathrm{X}_{2}$ dengan $\mathrm{Y}$ atau pengaruh keterampilan komunikasi karyawan kantor depan terhadap kepuasan pelanggan di Wisma DPR RI Bogor adalah sebagai berikut:

Tabel 4. Hasil Penghitungan Korelasi Linear Berganda

Model Summary

\begin{tabular}{|c|c|c|c|c|c|c|c|c|c|}
\hline \multirow[b]{2}{*}{ Model } & \multirow[b]{2}{*}{$\mathrm{R}$} & \multirow[b]{2}{*}{$\begin{array}{c}\mathrm{R} \\
\text { Square } \\
\end{array}$} & \multirow{2}{*}{$\begin{array}{c}\text { Adjusted } \\
\text { R } \\
\text { Square } \\
\end{array}$} & \multirow{2}{*}{$\begin{array}{l}\text { Std. Error } \\
\text { of the } \\
\text { Estimate }\end{array}$} & \multicolumn{5}{|c|}{ Change Statistics } \\
\hline & & & & & $\begin{array}{l}\text { R Square } \\
\text { Change }\end{array}$ & $\begin{array}{c}\mathrm{F} \\
\text { Change }\end{array}$ & df1 & $\mathrm{df} 2$ & $\begin{array}{l}\text { Sig. F } \\
\text { Change } \\
\end{array}$ \\
\hline 1 & $\begin{array}{r}.58 \\
2^{\mathrm{a}}\end{array}$ & ,339 & ,326 & 3,04162 & ,339 & 24,896 & 2 & 97 & ,000 \\
\hline
\end{tabular}

Sumber: Hasil Penelitian, 2020

Berdasarkan hasil hitung korelasi linear berganda dengan menggunakan SPSS didapatkan nilai $\rho$, koefisien korelasi adalah 0,582. Ini berarti hubungan antara nilai variabel keterampilan komunikasi karyawan kantor depan dengan nilai variabel kepuasan pelanggan memiliki korelasi penilaian kinerja berbasis e-kinerja dengan skor variabel efektivitas kerja memiliki korelasi sedang berdasarkan pedoman derajat hubungan.

Hasil perhitungan koefisiensi korelasi (r) sebesar 0,582 memerlukan pengujian signifikansi t hitung, sebagai berikut: 


$$
\begin{aligned}
\mathrm{t} & =\mathrm{r} \frac{\sqrt{n-2}}{\sqrt{1-r^{2}}} \\
& =0,582 \frac{\sqrt{100-2}}{\sqrt{1-0,582^{2}}} \\
& =0,582 \frac{\sqrt{98}}{\sqrt{1-0,339}} \\
& =0,582 \frac{\sqrt{98}}{\sqrt{0,661}} \\
& =0,582 \sqrt{148,26} \\
& =7,086
\end{aligned}
$$

Pedoman membandingkan pearson correlation dengan $r$ tabel adalah:

$\mathrm{r}$ hitung $>\mathrm{r}$ tabel $=$ berhubungan

$\mathrm{r}$ hitung $<\mathrm{r}$ tabel $=$ tidak berhubungan

Pengujian hubungan dua variabel penelitian dengan jumlah data sebanyak 100 data dengan taraf signifikan sebesar 3,211 dan menghasilkan thitung $(7,086)>t$ table $(1,660)$. Ini menunjukkan simpulan yang diambil adalah Ho ditolak dan Ha diterima. Keterampilan komunikasi karyawan kantor depan berpengaruh signifikan terhadap kepuasan tamu di Wisma DPR RI Bogor.

Sejauh mana variabel X (kemampuan komunikasi) memberikan kontribusi terhadap Y (kepuasan tamu) diukur dengan menggunakan koefisien determinasi. Koefisien determinasi merupakan perbandingan antara variabel $\mathrm{Y}$ yang dijelaskan oleh $\mathrm{X}_{1}$ dan $\mathrm{X}_{2}$ secara bersamasama dibandingkan dengan variabel total $\mathrm{Y}$. Jika selain $\mathrm{X}_{1}$ dan $\mathrm{X}_{2}$ semua variabel di luar model yang diwadahi dalam $\mathrm{E}$ dimasukkan ke dalam model, maka nilai $\mathrm{R}^{2}$ akan bernilai 1 . Nilai 1 untuk $\mathrm{R}^{2}$ berarti seluruh variasi $\mathrm{Y}$ dapat dijelaskan oleh variabel penjelas yang dimasukkan ke dalam model. Tidak ada ukuran yang pasti berapa besarnya $\mathrm{R}^{2}$ untuk menyimpulkan bahwa suatu pilihan variabel sudah tepat. Jika $\mathrm{R}^{2}$ semakin besar atau mendekati 1, maka model makin tepat. Penghitungan koefisien determinasi dalam penelitian ini adalah:

$$
\begin{aligned}
\mathrm{Kd} & =\mathrm{p}^{2} \times 100 \% \\
& =0,582^{2} \times 100 \% \\
& =0,339 \times 100 \% \\
\mathrm{Kd} & =33,9 \%
\end{aligned}
$$

Berdasarkan nilai koefisien determinasi sebesar 33,9 \% disimpulkan terdapat pengaruh yang sedang antara komunikasi karyawan kantor depan dan kepuasan tamu di Wisma DPR RI Bogor. Nilai koefisien determinasi cukup jauh dari 1 menunjukkan terdapat faktor lain yang mempengaruhi kepuasan tamu di Wisma DPR RI Bogor selain faktor keterampilan komunikasi karyawan kantor depan.

\section{KESIMPULAN DAN SARAN}

Keterampilan komunikasi karyawan kantor depan di Wisma DPR RI Bogor berdasarkan kriteria penafsiran tamu terhadap variabel X1 dan X2 termasuk kategori sangat baik dan baik. Ini menunjukkan kemampuan komunikasi verbal dan non verbal karyawan kantor depan dalam memberikan informasi telah baik. Ini direspon oleh penilaian tamu. Tamu menganggap kemampuan komunikasi verbal dan non verbal telah menunjukkan keterampilan dasar yang harus dimiliki oleh seorang karyawan kantor depan Wisma DPR RI Bogor. 
Tingkat kepuasan tamu berdasarkan hasil rekapitulasi jawaban responden terhadap variabel Y menunjukan nilai rata-rata 4,70. Ini berarti kepuasan tamu berada dalam kriteria penafsiran dalam kategori sangat baik. Tamu Wisma DPR RI Bogor telah merasa puas dengan kualitas produk, kualitas pelayanan, emosional, harga, dan biaya-biaya lain yang harus dikeluarkan tamu.

Hasil uji korelasi linear berganda menunjukan hipotesis yang diambil adalah Ho ditolak dan $\mathrm{Ha}$ diterima. Ini berarti dapat dinyatakan bahwa kemampuan komunikasi karyawan kantor depan Wisma DPR RI Bogor memiliki hubungan yang positif terhadap tingkat kepuasan tamu.

Nilai koefisien determinasi sedang menunjukkan terdapat faktor lain yang mempengaruhi kepuasan tamu di Wisma DPR RI Bogor selain faktor keterampilan komunikasi karyawan kantor depan. Faktor-faktor yang mungkin mempengaruhi kepuasan tamu selain kemampuan komunikasi karyawan kantor depan dapat diketahui melalui penelitian lain. Ini merupakan saran bagi penelitian selanjutnya.

\section{DAFTAR PUSTAKA}

Bagyono, 2016. Teori dan Praktek Hotel Front Office. Bandung: Penebit Alfabeta.

Chen, B. T. (2017). Service innovation performance in the hospitality industry: the role of organizational training, personal-job fit and work schedule flexibility. Journal of Hospitality Marketing \& Management, 26(5), 474-488.

Ghozali, Imam. 2011. Aplikasi Analisis Multivariate Dengan Program SPSS. Semarang: Badan Penerbit Universitas Diponegoro.

Hardjati, S., \& Febrianita, R. (2019). The power of interpersonal communication skill in enhancing service provision. Journal of Social Science Research, 14, 3192-3199.

Hidayat, Dasrun., 2012. Komunikasi antarpribadi dan medianya. Yogyakarta: Graha ilmu

Hussein, M. (2017). Guest Orientation of Front Office Employees' Service Quality and Rapport: Influences on Satisfaction in Egyptian Five and Four star Hotels. International Journal of Heritage, Tourism and Hospitality, 11(4 (Special Issue)), 159-177.

Insani, Y. D., \& Setiyariski, R. (2020). Meningkatkan Kualitas Pelayanan Front Office Department Melalui Tugas dan Tanggung Jawab Concierge Pada Hotel Savoy Homann. Jurnal Kajian Pariwisata, 2(1).

Kang, H. J. A., \& Busser, J. A. (2018). Impact of service climate and psychological capital on employee engagement: The role of organizational hierarchy. International Journal of Hospitality Management, 75, 1-9.

Kotler, Philip dan Keller., 2007. Manajemen Pemasaran, Jilid I, Edisi Kedua belas, PT. Indeks, Jakarta.

Mahafzah, A. G., Aljawarneh, N. M., Alomari, K. A. K., Altahat, S., \& Alomari, Z. S. (2020). Impact of customer relationship management on food and beverage service quality: The mediating role of employees satisfaction. Humanities \& Social Sciences Reviews, 8(2), 222-230.

Mulyana, A., \& Prayetno, S. (2018). Determinants of customer satisfaction and it's implication on customer loyalty of budget hotel in DKI Jakarta. International Review of Management and Marketing, 8(6), 1.

Nafik, Q. (2018). Peranan banquet sebagai pendukung pelayanan food and beverage service di hotel Luminor Jemursari Surabaya (Doctoral dissertation, Universitas Muhammadiyah Jember).

Nikmah, W., Emita, I., \& Boyratan, A. U. (2019). The Influence of Service to Customer Satisfaction in Diraja Hotel. Journal of Research in Business, Economics, and Education, 1(2). 
Ondy, F., \& Eleazar, E. (2017). Analisa persepsi konsumen terhadap komunikasi nonverbal resepsionis hotel bintang lima di surabaya. Jurnal Hospitality dan Manajemen Jasa, 5(2).

Permatasari, A. (2020). The Influence of Perceived Value Towards Customer Satisfaction in Hostel Business: A Case of Young Adult Tourist in Indonesia. International Journal of Tourism and Hospitality Management in the Digital Age (IJTHMDA), 4(2), 11-22.

Pope, Sharon (2015) Strategies for Developing Interpersonal Communication Skills for Business Students Walden Dissertations and Doctoral Studies Collection

Prayoga, Y. A. (2020). Pentingnya Peranan Chef Dalam Struktur Organisasi Dapur Terhadap Kualitas Produk Dan Kinerja Karyawan Di Sheraton Surabaya Hotel \& Towers (Doctoral dissertation, Universitas Airlangga).

Putra, Y. W. W. (2019). Penilaian kinerja karyawan kantor depan di D'best Hotel Bandung.

Riduwan. 2012. Metode \& Teknik Menyusun Proposal Penelitian. Bandung: Alfabeta

Rossanty, Y., Nasution, M. D. T. P., \& Irawan, I. (2019). Communication and Customer Relations Strategy in Improving Hotel Guests' Satisfaction in Samosir Tourism Area, North Sumatra, Indonesia. International Journal of Management (IJM), 10(6).

Sayın, K., \& Karaman, A. (2018). Communication and Productivity with Customers at Front Office; A Qualitative Study on Hotels. Tourism, Business And Technology (ICTBT 2018), 1.

Shao, Y. (2017). The Effect of Front Desk Employees' Characteriestics on the First Impression of Customers and Customers' Satisfaction. University of MissouriColumbia.

Silaban, P. H., Pasaribu, A., \& SIlalahi, A. D. (2019). The influence of human aspect of accommodation and destination on tourist satisfaction. International Journal of Innovative Technology and Exploring Engineering, 8(7), 985-995.

Simanjuntak, D. (2020). Analisis Interaksi Simbolik Nonverbal Frontliner dalam Pelayanan Hotel Berbintang di Kota Bandung. Tourism Scientific Journal, 5(2), 209-230.

Sudantari, N. N., Padmadewi, N. N., \& Dewi, K. S. (2019). The Use of Verbal and NonVerbal Communication by Front Office Staff to Guest at Double-Six Luxury Hotel Seminyak. Jurnal Pendidikan Bahasa Inggris undiksha, 7(2), 42-51.

Sugiyono, 2013. Metode Penelitian Kuantitatif, Kualitatif dan R\&D. Bandung: Alfabeta.CV

Sukamerta, I. K. N., \& Andiani, N. D. (2020). Penanganan Keluhan Tamu dengan Metode ILEAD Oleh Karyawan Kantor Depan di Hotel Holiday Inn Resort Baruna Bali. Jurnal Manajemen Perhotelan dan Pariwisata, 3(1), 36-41. 